\title{
OECONOMIA
}

COPERNICANA

\section{VOLUME 12 ISSUE 1 MARCH 2021}

\author{
p-ISSN 2083-1277, e-ISSN 2353-1827 \\ www.oeconomia.pl
}

\section{ORIGINAL ARTICLE}

Citation: Hashemkhani Zolfani, S., Ebadi Torkayesh, A., Ecer, F., Turskis, Z., \& Šaparauskas, J. (2021). International market selection: a MABA based EDAS analysis framework. Oeconomia Copernicana, 12(1), 99-124. doi: 10.24136/oc.2021.005

Contact to corresponding author: sa.hashemkhani@gmail.com; Catholic University of the North, School of Engineering, Larrondo 1281, Coquimbo, Chile

Received: 10.10.2020; Revised: 13.01.2021; Accepted: 23.01.2021; Published online: 30.03.2021

\section{Sarfaraz Hashemkhani Zolfani}

Catholic University of the North, Chile

(iD) orcid.org/0000-0002-2602-3986

\section{Ali Ebadi Torkayesh}

Sabanci University, Turkey

(iD) orcid.org/0000-0002-1012-4213

\section{Fatih Ecer}

Afyon Kocatepe University, Turkey

(D) orcid.org/ 0000-0002-6174-3241

\section{Zenonas Turskis}

Vilnius Gediminas Technical University, Lithuania

(iD) orcid.org/0000-0002-5835-9388

\section{Jonas Šaparauskas}

Vilnius Gediminas Technical University, Lithuania

(iD) orcid.org/0000-0003-3685-7754

\section{International market selection: a MABA based}

\section{EDAS analysis framework}

\author{
JEL Classification: $O 21 ; C 02 ; F 21$
}

Keywords: international market selection; EDAS; General Electric (GE) Matrix; McKinsey matrix; MABA analysis

\footnotetext{
Abstract

Research background: International market selection is an essential issue for big companies that supply food products. Different types of decision factors and different characteristics of different
} 
international markets have brought up a complicated decision-making problem for food supply companies. In order to select the most suitable and profitable market, food supply companies have to consider several qualitative and quantitative factors, including social, political, economic, and ecological aspects.

Purpose of the article: In order to overcome international market selection issues, the current study develops a novel integrated decision-making tool.

Methods: A novel decision-making model of market analysis is developed as an extended model of Market Attractiveness and Business Attractiveness (MABA) analysis based on the Multiple Attribute Decision Making (MADM). To improve the MABA analysis model, we combine the EDAS method with MABA analysis to empower decision-makers in food supply companies to evaluate several international markets and select the most profitable market for their products.

Findings \& value added: In this study, we first identified the most important and frequently used decision factors for market analysis problems within MABA analysis under two categories: market attractiveness and business attractiveness. To show the proposed methodology's applicability and feasibility, we perform a case study for a food supply company in Iran that supplies products to Middle East and Asian countries. In order to investigate the reliability of the obtained results, we perform a sensitivity analysis concerning the importance of involved decision factors. The proposed decision-making tool results suggest that the model can be used as a reliable tool for market analysis problems. To sum up the long-term value of the study, we have developed a novel decision-making tool using MABA analysis and the EDAS method. No study integrates any MCDM methods with MABA analysis to the best of our knowledge. Integration of EDAS method with MABA analysis empowers decision-makers in market selection division to use more systematic methods for evaluating several markets.

\section{Introduction}

Supply chain management (SCM) is an important framework that focuses on cost, time, and quality of products through different operations, from supplier selection to manufacturing means and transportation and logistics modes (Ecer, 2020a). One of the important problems in SC operations' last layers is international/foreign market selection (Clark et al. 2018). Ragland et al. (2015) claimed that entry mode selection and international market selection (IMS) are considered the two most significant internationalization decisions. As one of the most crucial decisions in foreign market entry strategy (Marchi et al., 2014), IMS refers to determining the target market(s) where a company wants to offer its product (Górecka \& Szałucka, 2013). IMS, a strategic decision, analyzes how a company chooses overseas target markets (Ragland et al., 2015). In this context, IMS is not only a crucial module of the success of firms but also an important aspect of identifying abroad performance (Al Qur'an, 2020; Ramadani et al., 2018; Ragland et al. 2015).

Such a problem, managers and decision-makers are focused on selecting the most suitable and profitable market with respect to nature of the product and so many other factors related to technical, economic, social, and environmental aspects (He et al., 2016; Cachon, 1999; Mentzer et al., 2001; 
Zhu et al., 2008). In other words, the foreign market's choice to be entered is a rather crucial decision in the strategy of entering the international market (Oey et al. 2018). Rahman (2003) showed that the main reason for export failure is poor market selection. As a result, decision-making process for such strategic management problems requires reliable decision-making tools that can be used in order to facilitate the evaluation process among all potential markets. Further, since the analysis in foreign market selection can be performed qualitatively or quantitatively (Papadopoulos and Denis, 1988), a quantitative approach is preferred in this study.

Market Attractiveness and Business Attractiveness (MABA) analysis, referred to as "General Electric (GE) Matrix" or "McKinsey Matrix" is one of the most practical strategic and market planning tools. MABA analysis was done for the General Electric company, which is mainly called General Electric Matrix. MABA analysis is really useful for internal and microanalyses at the organizational level. Therefore, companies will be able to find their strategic position in the market. Although MABA analysis can be categorized as a qualitative strategic research tool, some tend to quantitative calculation and analysis. As a model, this strategic tool uses a simple weighting system and a pointing system to the market as possible alternatives to a decision-making problem. Hence, there is a similarity between this concept and the Multiple Attribute Decision Making (MADM) outline. MADM framework has been developing in parallel with MABA analysis being created, and these topics could not meet each other. MADM models are among well-known and extensively developed decision-making tools in the literature of strategic decision-making for SCM (Ecer and Pamucar, 2020). MADM methods are applied in two main ways to address a problem that involves multiple factors. In this regards, methods like Analytical Hierarchal Process (AHP), Shanon Entropy, Best-Worst Method (BWM), Step-wise Weight Assessment Ratio Analysis (SWARA), Full Consistency Method (FUCOM), Level Based Weight Assessment (LBWA), CRiteria Importance Through Inter-criteria Correlation (CRITIC), etc., are used to determine the importance of decision factors (Rezaei, 2015; Ecer, 2020b; Yazdani et al., 2019a; Ecer, 2015; Žižović \& Pamucar, 2019; Hashemkhani Zolfani et al., 2020a; Torkayesh et al., 2020a; Hashemkhani Zolfani et al., 2020b; Torkayesh et al., 2020b; Pamucar et al., 2020; Yazdani et al., 2020a, Yazdani et al., 2020b). Furthermore, MADM models are among the top decision-making models that can be employed to evaluate or prioritize a set of alternatives. For this purpose, methods such as Technique for Order of Preference by Similarity to Ideal Solution (TOPSIS), VIseKriterijumska Optimizacija I Kompromisno Resenje (VIKOR), Evaluation Based on the Distance from the Average Solution (EDAS), Combinative Distance-based 
Assessment (CODAS), Combined Compromise Solution (CoCoSo), Measurement of alternatives and ranking according to COmpromise solution (MARCOS), etc., can be applied to make a logical evaluation framework in order to make a ranking order for a set of alternatives considering multiple factors (Keshavarz Ghorabaee et al., 2015; Keshavarz Ghorabaee et al., 2016; Yazdani et al., 2019b; Ebadi Torkyaesh et al., 2019; Stević et al., 2020; Zolfani et al., 2020). In this paper, we develop a novel decisionmaking model for strategic decision-making for market analysis. For this purpose, we integrate the EDAS method with the traditional GE Matrix to calculate the relative score for each market alternative in a systematic way. In order to show the applicability of the proposed decision-making model, a case study of the market selection problem is considered for a food supplier in the Middle East.

Our main contribution is to develop a model to make MABA stronger through a MADM tool, i.e., EDAS, for IMS. The only significant restriction in our analysis is the intuitive determination of factor weights used for this purpose. Along with the analyses, we demonstrate that the MABA, which has been further strengthened with EDAS, is an effective and useful IMS tool. Common arguments in favor of the IMS rely on what kind of method (statistical, mathematical programming, multiple-criteria, etc.) is necessary to handle; hence, in this work, we analyze IMS through EDAS based MABA analysis. Moreover, to show the effectiveness and usefulness of the suggested framework, we conduct a sensitivity analysis.

Our first main finding is that the proposed model can take many factors into account at the same time. In such markets, market growth, market size, competition level, relative market share, brand popularity, etc. can be very similar. Analyzes without considering the above factors together are far from giving real results. Another of our main findings is that the proposed framework can successfully differentiate foreign markets from each other. In many IMS problems, alternative markets have similar characteristics. Hence, it is unlikely to determine the most profitable market intuitively. In a nutshell, the proposed model clearly determines each alternative foreign market's performance and thus offers a decision support system to company owners, senior managers, and policymakers.

\section{Literature review}

In order to formalize the decision-making process, not surprisingly, plenty of studies has been done in the field of IMS so far, such as Brouthers and Nakos (2005), Marchi et al. (2014), Budeva and Mullen (2016), Buckley 
(2017), Schühly and Tenzer (2017), Schu and Morschett (2017), Ahi et al. (2019), and Mersland et al. (2020) among others.

As per Kotler (2019) and Root (1994), IMS is a key international market entry strategy element. However, Koch (2001) asserted that comprehensive studies on this subject were scarce. A study by Andersen and Buvik (2002) argued that there are three approaches in order to perform IMS: a systematic, a non-systematic, and a relationship option. Some models introduced in the past used preliminary screening, in-depth screening, and selection stages to assess foreign markets (Root, 1994; Koch, 2001). However, current approaches can fail to satisfy in solving the problem of IMS.

Furthermore, there is a risk that the proposed solution to the IMS problem could fail to match the firm's sources and goals (Marchi et al., 2014). Papadopoulos and Martín (2011) stated that IMS methodologies need to be flexible, in-depth, and cost-effective. Musso and Francioni (2014) found that small- and medium-sized enterprises have a non-systematic behavior during IMS. Moreover, they noted that larger firms utilize resources and competencies more successfully to manage their decision processes better. In another paper, Clark et al. (2018) argued that a manager's country familiarity impacts the decision process and result. Using a database of Chinese manufacturing firms, He et al. (2016) conducted a transaction cost analysis regarding the exporting companies' selection of the international market's performance outcomes. The economic approach and the behavioral approach were offered as two essential approaches in evaluating alternative foreign markets by Andersson (2000). According to the economic approach, firms prefer the most profitable markets. On the other hand, the critical role of organizational knowledge in internationalization is the main focus of the behavioral approach (Al Qur'an, 2020).

In the marketing field, a state-art of reviewing criteria reveals that market size and the level of economic development are the most preferred criteria (He et al., 2016; Natarajarathinam \& Nepal, 2012; Sheng \& Mullen, 2011; Whitelock \& Jobber, 2004). Additionally, production factors (Dunning, 1988; Marchi et al., 2014), market size (Ozturk et al., 2015; Natarajarathinam \& Nepal, 2012), market intensity (Sheng \& Mullen, 2011), risk potential of the country (Natarajarathinam \& Nepal, 2012), political and economic stability (Whitelock \& Jobber, 2004; Ozturk et al., 2015), proximity to the country (Marchi et al., 2014; Sheng \& Mullen, 2011), language and religious differences (Clark et al., 2018; Whitelock \& Jobber, 2004), and profit (Ozturk et al., 2015) are among the other most emphasized criteria. Another study found that the target country's culture and country knowledge are the IMS's main drivers (Budeva \& Mullen, 2016). 
In order to maximize the profit a company, strategic decision-making models can enable managers to allocate their financial resources in different kinds of markets with different shares. As noted above, MABA analysis is one of the strategic decision-making models that has been applied to a strategic position in markets (Hofer \& Schendler, 1978; Paley, 1999). MABA analysis model has been rarely used as an important strategic decision-making model in the literature. A study by Amatulli et al. (2011) developed an evaluation framework for the Italian fashion industry using GE Matrix to assess product-portfolio management for four popular fashion companies. Decuseara (2013) used MABA analysis to select suitable foreign markets in Europe, considering several factors for market and business attractiveness aspects. Shen et al. (2015) proposed a strategic decisionmaking model using MABA analysis and the Shanon Entropy method. The proposed model was used to evaluate sustainable urbanization considering two development index and coordination index groups for a case study in China. In a similar study, Yang and Jiang (2018) used MABA analysis evaluating sustainable urbanization of resource-based cities in China. The evaluation framework was built on the urbanization index and ecoefficiency index, where the Shanon Entropy method was used to determine the importance of factors and sub-factors.

EDAS is one of the recently developed MADM models used to prioritize a set of alternatives regarding multiple factors (Keshavarz Ghorabee et al., 2015). Kahraman et al. (2017) developed a new version of EDAS method under fuzzy set theory. The proposed model was used to evaluate the waste disposal site locations. Ghorabaee et al. (2018) used a fuzzybased EDAS method to prioritize construction equipment and materials considering sustainability factors. Torkayesh et al. (2020b) developed a hybrid MADM model using the Shanon Entropy method and EDAS method. The proposed decision-making model has applied a neighborhood selection problem for a new international student who wants to be located in Istanbul, Turkey. Behzad et al. (2020) used a hybrid decision-making model with the aid of BWM and EDAS models to make an evaluation framework in order to assess waste management status in Nordic countries.

It is concluded that several models (see Vahlne \& Johanson, 2013; Reid, 1981; Johanson \& Wiedersheim-Paul, 1975), statistical and econometric techniques (Budeva \& Mullen, 2016; He et al., 2016; Kinuthiaa \& Murshed, 2015), and theories (Dunning, 2015; Vernon, 1992; Johanson \& Mattsson, 1987) have been handled in most of the previous studies in the current body of knowledge. Additionally, only a few studies addressed MADM methods like TOPSIS (Christian et al., 2016), AHP (Sener, 2014; Aghdaie \& Alimardani, 2015), and VIKOR (Tosun, 2017). This work aims 
to introduce an integrated methodology referred as EDAS-MABA model to contribute to the available IMS field. The originality of the study comes from it has not been addressed before. Further, a model has been developed to help make more effective IMS decisions using two methods.

\section{Methodology}

This section proposes a novel decision-making framework to address market analysis problems using the GE matrix and EDAS method. In the first section, a brief description is given over GE matrix or MABA analysis, and then a brief description is given about steps of the EDAS method.

\section{GE Matrix}

GE/McKinsey Matrix, or in other words, the MABA analysis model, was first developed by a group of researchers in the GE Company with a group of researchers from McKinsey consulting company (Robinson et al., 1978). The GE matrix is composed of a $3 * 3$ grid with market attractiveness and business attractiveness axis. These factors are being measured on a scale of the high, medium, and low score (Figure 1). Companies employed the proposed model to find the most suitable and optimal investment opportunities among a series of market alternatives. In order to make comparisons among portfolios and markets, MABA analysis considers a set of potential alternatives and a set of relevant factors that would be used to prioritize the portfolios, brands, or markets. In this model, each factor is given specific importance by the decision-maker. This assigned value shows the importance or contribution of a specific factor in the evaluation of alternatives in MABA analysis. After the determination of the significance of each factor, one or a group of decision-makers score for each alternative concerning each factor. In the traditional GE matrix, each alternative's final score is calculated based on a summation of multiplied weight and scores. After the determination of scores for market attractiveness and business attractiveness factors, a plot is drawn. This includes the position of each alternative.

\section{Evaluation based on the distance from the average solution (EDAS)}

Keshavarz Ghorabaee et al. (2015) developed a new ranking MADM model, called EDAS, to address multi-criteria problems. In this method, alternatives are prioritized with respect to their distance from the average 
solution. Steps of the EDAS method for a MADM with $n$ alternatives and $m$ criteria are defined below.

Step 1. In this step, the decision-maker constructs the initial decision matrix.

Step 2. The average solution for each criterion is calculated based on equations.

$$
\begin{aligned}
A V & =\left[A V_{j}\right]_{1 \times m} \\
A V_{j} & =\frac{\sum_{i=1}^{n} X_{i j}}{n}
\end{aligned}
$$

Step 3. Positive distance from average (PDA) and negative distance from average (NDA) are calculated. Equations (5) and (6) are used for benefit criteria, and equations (7) and (8) are used for cost criteria.

$$
\begin{gathered}
P D A=\left[P D A_{i j}\right]_{n \times m} \\
N D A=\left[N D A_{i j}\right]_{n \times m} \\
P D A_{i j}=\frac{\max \left(0,\left(X_{i j}-A V_{j}\right)\right)}{A V_{j}} \\
N D A_{i j}=\frac{\max \left(0,\left(A V_{j}-X_{i j}\right)\right)}{A V_{j}} \\
P D A_{i j}=\frac{\max \left(0,\left(A V_{j}-X_{i j}\right)\right)}{A V_{j}} \\
N D A_{i j}=\frac{\max \left(0,\left(X_{i j}-A V_{j}\right)\right)}{A V_{j}}
\end{gathered}
$$

Step 4. We calculate the weighted sum of PDA and NDA for all alternatives.

$$
\begin{gathered}
S P_{i}=\sum_{j=1}^{m} w_{j} P D A_{i j} \\
S N_{i}=\sum_{j=1}^{m} w_{j} N D A_{i j}
\end{gathered}
$$


Step 5. We normalize the obtained values in step 4. These values are then added and construct a new vector, called NSP and NSN.

$$
\begin{gathered}
N S P_{i}=\frac{S P_{i}}{\max _{i}\left(S P_{i}\right)} \\
N S N_{i}=1-\frac{S N_{i}}{\max _{i}\left(S N_{i}\right)}
\end{gathered}
$$

Step 6. Finally, appraisal score (AS) for each alternative is calculated.

$$
A S_{i}=\frac{1}{2}\left(N S P_{i}+N S N_{i}\right)
$$

\section{A case study in a food exporter company}

A food market selection case study for a large food exporter company in Iran has been investigated to show the proposed methodology's applicability and feasibility. The food exporter is one of the largest food industry companies in the Middle East, which supplies different kinds of fruits for more than 15 countries in the Middle East and Asia. This case study is selected because of the access that authors could have, and the company was a volunteer for the study. Two authors of the current study are Iranians who work in other countries.

In this section, the GE matrix, MABA analysis, has been applied to select the best market alternatives regarding related factors. In this regard, six potential markets are identified to be evaluated in order to select the most profitable one for the food exporter company. To make an evaluation framework using MABA analysis, two groups of factors, called Market Attractiveness factors and Business Attractiveness factors, are identified for the following problem. Market attractiveness factors $\left(C_{1}\right)$ are as follows: market size $\left(\mathrm{C}_{1-1}\right)$, annual market growth $\left(\mathrm{C}_{1-2}\right)$, market competition level $\left(\mathrm{C}_{1-3}\right)$, price sensitivity $\left(\mathrm{C}_{1-4}\right)$, the employment rate $\left(\mathrm{C}_{1-5}\right)$. Business attractiveness factors $\left(\mathrm{C}_{2}\right)$ are as follows: relative market share $\left(\mathrm{C}_{2-1}\right)$, growth of share $\left(\mathrm{C}_{2-2}\right)$, brand popularity $\left(\mathrm{C}_{2-3}\right)$, profit $\left(\mathrm{C}_{2-4}\right)$, future expansion potential $\left(\mathrm{C}_{2-5}\right)$. We identified from the current literature those criteria that were best suited to the expert's strategic orientation and the food industry context (Marchi et al., 2014; Schoemaker, 2017). Market attractiveness and Business attractiveness have some explicit narrow areas, and the most crucial criteria can be similar in the different studies. In this research, the main 
criteria have been selected based on Shoemaker (2017) and criteria justified in a more specific context as Marchi et al. (2014) was presented.

There is no consensus on how the criteria weights can be assigned. Some researchers argued that all criteria should be of equal importance (Papadopoulos \& Martín, 2011), while others stated that certain criteria may be more important than others (Cavusgil et al., 2004). In this work, an international business professional in the food sector is asked to determine each factor's importance. As shown in Table 1, each factor is given a value between 0 and 1, which shows how much a factor contributes to the problem. It is needless to mention that the summation of all weight values in each factor group should be equal to 1 . In the next steps, the decisionmaker is asked to give each market an alternative score concerning defined factors for both market attractiveness and business attractiveness factors. A scale of 1 to 100 is used to evaluate and score each market alternatives. Scores of market alternatives concerning market attractiveness factors are given in Table 2. In the same manner, scores for market alternatives with respect to business attractiveness are given in Table 3 .

After determining each market's evaluation scores under each factor, we determine each market's final score using the EDAS method. In this regard, NSP, and NSN values are obtained using Table 2 and Table 3. The obtained NSN and NSP values are used to calculate each market's final score value, which is represented in Table 4 for market attractiveness factors and in Table 5 for business attractiveness factors.

As shown in Table 5, the final results for market scores show how suitable these markets are for the food supplier company. Figure 2 shows the GE Matrix for the considered markets in this case study. Based on the results, market three and market 4 are the two main profitable markets places for the food supplier company's food products.

\section{Sensitivity analysis}

Expert's judgments for the weight determination process can be biased and subjective due to their experience and background. The weight determination process is the most critical process for a MCDM problem. So, in order to verify the results obtained from the EDAS method for the performance of markets under both market attractiveness and business attractiveness, we perform a sensitivity analysis on weight coefficients of decision criteria. In this regard, we aim to analyze the effect of the changes of the most important criterion in both market attractiveness and business attractiveness groups in the final scores of each market. For this purpose, we simulate 20 weight scenarios using equation (14). 


$$
\omega_{n \beta}=\left(1-\omega_{n a}\right) \frac{\omega_{\beta}}{\left(1-\omega_{n}\right)}
$$

In equation (14), $\omega_{n \beta}$ shows the adjusted value of the criterion, $\omega_{n a}$ indicates the reduced value of the most crucial criterion, $\omega_{\beta}$ denotes the original value of the criterion, $\omega_{n}$ denotes the original value of the most important criterion. The reductions in the most important criterion's value occur with a rate of $5 \%$ in each scenario. We simulate the weight vectors for both groups of criteria, considering the most crucial criterion in each one of them. Detailed information of generated weight scenarios is represented in Table 6.

Figures 3 and 4 represent the graphical changes of weight coefficients in each simulated weight scenario for market attractiveness criteria and business attractiveness criteria, respectively.

After the generation of simulated weight scenarios based on the most important criterion in each group of criteria, we apply the EDAS method to obtain each market's performance score with respect to both market attractiveness and business attractiveness criteria. The EDAS method results for all market alternatives under all weight scenarios are represented in Table 7.

\section{Discussion and managerial implications}

Strategic management or planning has been growing in a descriptive qualitative scheme for many decades. There are many efforts by the researchers to bring more quantitative methods and tools to prepare a better tangible strategic framework. As it can be seen in the literature, there are numerous studies on applying qualitative methods for some strategic planning topics based on SWOT (Imran Khan, 2018; Solangi et al., 2019; Li et al., 2020) and Balanced Scorecard (BSC) (Varmazyar et al., 2016; Lu et al., 2018; Dincer \& Yuksel, 2019).

Strategic management can be divided into four main categories: strategic approaches, strategic creation, organizational structures, strategy formulation, and strategic evaluation (Fuertes et al., 2020). Multiple Criteria Decision Making (MCDM) approaches, and methods can be defined and applied for strategy formulation and, more importantly, strategic evaluation. This is how MCDM can contribute to the strategic management field, as discussed in this study.

MABA analysis is still a common strategic planning tool and has been taught to under-graduate and post-graduate students worldwide. MABA, 
itself has a quantitative perspective in evaluating and positioning the markets. This general approach has a similarity to the classic form of MCDM methods. This issue was the main research gap of this study. The authors showed how MCDM methods could be applied in the MABA analysis to prepare a better evaluation and analysis form. There is no similar study to the proposition given in the current article. This is the first time a mathematical method (quantitative form) is adding to the qualitative form of MABA analysis.

Hence, by applying a new-common MCDM method, EDAS, MABA can experience a new aliveness again as a sample. Although MABA analysis is still a common teaching tool, few new studies on the classic platform are a strategic planning tool. It means MABA, anymore, is a limited tool that didn't have enough potential for evaluating markets. On the other hand, MCDM methods themselves won't evaluate markets without any specific platform on a specialized strategic planning tool. This new hybrid model can contribute to the strategic planning, marketing, and MCDM fields. Eventually, plotting different strategic market positioning based on MABA and in a quantitative form will increase strategic decisions' accuracy and outputs.

\section{Conclusions}

Large food supplier companies have faced several challenges through selecting the most profitable and suitable market for their food products. Market selection problem is considered one of the important parts of supply chain management where final products will be transmitted through distribution centers to outside markets to purchase their food demands. GE Matrix has been developed for several years in order to make an evaluation framework for assessing market alternatives in terms of market attractiveness factors and business attractiveness factors.

In this study, as our main contribution, we proposed a novel integrated decision-making model that can be considered a reliable decision-making tool for market analysis problems. In the proposed decision-making model, the EDAS method is used within GE Matrix to calculate each market alternative's score more systematically to increase the obtained results' reliability. To show how efficient the proposed model can work, we considered a market selection problem for a large food supplier company in the Middle East.

The main limitation of market studies in such countries in the Middle East is the instability of the markets, especially the currencies' international 
rate. Sometimes companies need to consider different scenarios in their market studies. Meanwhile, changes are usually helpful for export to other countries that is not necessarily a disadvantage.

For future works, this study can be extended in several ways. One may use another method instead of EDAS for the calculation of scores. The proposed model can be applied for other market analysis problems in other industries with different factors. In another way, one may consider a systematic weight determination process for the importance of market and business attractiveness factors. An uncertain situation may consider the evaluation and corresponding scores in uncertain numbers such as fuzzy numbers.

\section{References}

Aghdaie, M. H., \& Alimardani, M. (2015). Target market selection based on market segment evaluation: a multiple attribute decision making approach. International Journal of Operational Research, 24(3), 262-278. doi: 10.1504/IJOR.2015.072231.

Ahi, A., Kuivalainen, O., \& Bahreinian, M. (2019). A systematic approach to international market selection: measuring the attractiveness of emerging economies in the case of the timber industry. International Journal of Export Marketing, 3(2), 105-118. doi: 10.1504/IJEXPORTM.2019.104396.

Al Qur'an, M. (2020). Success factors influencing the selection of the location of international firms. Competitiveness Review: An International Business Journal, 30(5), 665-679. doi: 10.1108/CR-05-2018-0030.

Amatulli, C., Caputo, T., \& Guido, G. (2011). Strategic analysis through the general electric/McKinsey Matrix: an application to the Italian fashion industry. International Journal of Business and Management, 6(5), 61. doi: 10.5539/ijbm .v6n5p61.

Andersen, O., \& Buvik, A. (2002). Firms' internationalization and alternative approaches to the international customer/market selection. International business review, 11(3), 347-363. doi: 10.1016/S0969-5931(01)00064-6.

Andersson, S. (2000). The internationalization of the firm from an entrepreneurial perspective. International Studies of Management \& Organization, 30(1), 6392. doi: 10.1080/00208825.2000.11656783.

Behzad, M., Zolfani, S. H., Pamucar, D., \& Behzad, M. (2020). A comparative assessment of solid waste management performance in the Nordic countries based on BWM-EDAS. Journal of Cleaner Production, 122008. doi: 10.1016/ j.jclepro.2020.122008.

Brouthers, L. E., \& Nakos, G. (2005). The role of systematic international market selection on small firms' export performance. Journal of Small Business Management, 43(4), 363-381. doi: 10.1111/j.1540-627X.2005.00142.x. 
Buckley, P. J. (2017). The competitiveness of emerging country multinational enterprise. Competitiveness Review: An International Business Journal, 27(3), 208-216. doi: 10.1108/CR-03-2016-0017.

Budeva, D., \& Mullen, M. R. (2016). Does culture matter for international market selection? International Journal of Export Marketing, 1(2), 193-214. doi: 10.1504/IJEXPORTM.2016.081570.

Cachon, G. P. (1999). Competitive supply chain inventory management. In Quantitative models for supply chain management. Boston, MA: Springer, 111-146.

Cavusgil, S. T., Kiyak, T., \& Yeniyurt, S. (2004). Complementary approaches to preliminary foreign market opportunity assessment: country clustering and country ranking. Industrial Marketing Management, 33(7), 607-617. doi: 10.10 16/j.indmarman.2003.10.005.

Christian, A. V., Zhang, Y., \& Salifou, C. K. (2016). Country selection for international expansion: TOPSIS method analysis. Modern Economy, 7(04), 470. doi: 10.4236/me.2016.74052.

Clark, D. R., Li, D., \& Shepherd, D. A. (2018). Country familiarity in the initial stage of foreign market selection. Journal of International Business Studies, 49(4), 442-472. doi: 10.1057/s41267-017-0099-3.

Decuseara, N. R. (2013). Using the general electric/Mckinsey Matrix in the process of selecting the central and east European markets. Management Strategies Journal, 19(1), 59-66.

Dincer, H., \& Yuksel, S. (2019). An integrated stochastic fuzzy MCDM approach to the balanced scorecard-based service evaluation. Mathematics and Computers in Simulation, 166, 93-112. doi: 10.1016/j.matcom.2019.04.008.

Dunning, J. H. (1988). The theory of international production. International Trade Journal, 3(1), 21-66. doi: 10.1080/08853908808523656.

Dunning, J. H. (2015). The eclectic paradigm of international production: a restatement and some possible extensions. In The eclectic paradigm. London: Palgrave Macmillan, 50-84.

Ebadi Torkayesh, A., Fathipoir, F., \& Saidi-Mehrabd, M. (2019). Entropy-based multi-criteria analysis of thermochemical conversions for energy recovery from municipal solid waste using guzzy VIKOR and ELECTRE III: vase of Azerbaijan region, Iran. Journal of Energy Management and Technology, 3(1), 17-29. doi: 10.22109/JEMT.2018.134505.1098.

Ecer, F. (2015). Performance evaluation of internet banking branches via a hybrid MCDM model under fuzzy environment. Economic Computation \& Economic Cybernetics Studies \& Research, 49(2), 211-230.

Ecer, F. (2020a). An analysis of the factors affecting wind farm site selection through FUCOM subjective weighting method Pamukkale University Journal of Engineering Sciences, 27(1), 24-34. doi: 10.5505/pajes.2020.93271.

Ecer, F. (2020b). Multi-criteria decision making for green supplier selection using interval type-2 fuzzy AHP: a case study of a home appliance manufacturer. Operational Research. Advance online publication. doi: 10.1007/s12351020-00552-y. 
Ecer, F., \& Pamucar, D. (2020). Sustainable supplier selection: a novel integrated fuzzy best worst method (F-BWM) and fuzzy CoCoSo with Bonferroni (CoCoSo'B) multi-criteria model. Journal of Cleaner Production, 121981. doi: 10.1016/j.jclepro.2020.121981.

Fuertes, G., Alfaro, M., Vargas, M., Gutierrez, S., Ternero, R., \& Sabattin, J. (2020). Conceptual framework for the strategic management: a literature review-descriptive. Journal of Engineering, 6253013. doi: 10.1155/2020/625 3013.

Ghorabaee, M. K., Amiri, M., Zavadskas, E. K., \& Antucheviciene, J. (2018). A new hybrid fuzzy MCDM approach for evaluation of construction equipment with sustainability considerations. Archives of Civil and Mechanical Engineering, 18(1), 32-49. doi: 10.1016/j.acme.2017.04.011.

Górecka, D., \& Szałucka, M. (2013). Country market selection in international expansion using multicriteria decision aiding methods. Multiple Criteria Decision Making, 8, 32-55.

Hashemkhani Zolfani, S., Ecer, F., Pamučar, D., \& Raslanas, S. (2020). Neighborhood selection for a newcomer via a novel BWM-based revised MAIRCA integrated model: a case from the Coquimbo-La Serena conurbation, Chile. International Journal of Strategic Property Management, 24(2), 102118. doi: 10.3846/ijspm.2020.11543.

Hashemkhani Zolfani, S., Yazdani, M., Ebadi Torkayesh, A., \& Derakhti, A. (2020). Application of a Gray-based decision support framework for location selection of a temporary hospital during COVID-19 pandemic. Symmetry, 12(6), 886. doi: 10.3390/sym12060886.

He, X., Lin, Z., \& Wei, Y. (2016). International market selection and export performance: a transaction cost analysis. European Journal of Marketing, 50(5/6), 916-941. doi: 10.1108/EJM-02-2013-0083.

Hofer, C. W., \& Schendel, D. (1978). Strategy formulation: analytical concepts. St. Paul, MN: West Publishing Company.

Imran Khan, M. (2018). Evaluating the strategies of compressed natural gas industry using an integrated SWOT and MCDM approach. Journal of Cleaner Production, 172, 1035-1052. doi: 10.1016/j.jclepro.2017.10.231.

Johanson, J., \& Mattsson, L. G. (1987). Interorganizational relations in industrial systems: a network approach compared with the transaction-cost approach. International Studies of Management \& Organization, 17(1), 34-48.

Johanson, J., \& Wiedersheim-Paul, F. (1975). The internationalization of the firm: Four Swedish cases. Journal of Management Studies, 12(3), 305-322. doi: 10.1111/j.1467-6486.1975.tb00514.x.

Kahraman, C., Keshavarz Ghorabaee, M., Zavadskas, E. K., Cevik Onar, S., Yazdani, M., \& Oztaysi, B. (2017). Intuitionistic fuzzy EDAS method: an application to solid waste disposal site selection. Journal of Environmental Engineering and Landscape Management, 25(1), 1-12. doi: 10.3846/16486897.201 7.1281139 . 
Keshavarz Ghorabaee, M., Zavadskas, E. K., Turskis, Z., \& Antucheviciene, J. (2016). A new combinative distance-based assessment (Codas) method for multi-criteria decision-making. Economic Computation \& Economic Cybernetics Studies \& Research, 50(3), 25-44.

Keshavarz Ghorabaee, M., Zavadskas, E. K., Olfat, L., \& Turskis, Z. (2015). Multi-criteria inventory classification using a new method of evaluation based on distance from average solution (EDAS). Informatica, 26(3), 435-451. doi: 10.15388/Informatica.2015.57.

Kinuthia, B. K., \& Murshed, S. M. (2015). FDI determinants: Kenya and Malaysia compared. Journal of Policy Modeling, 37(2), 388-400. doi: 10.1016/j.jpolmod .2015.01.013.

Koch, A. J. (2001). Selecting overseas markets and entry modes: two decision processes or one? Marketing Intelligence \& Planning, 19(1), 65-75. doi: 10.11 08/02634500110366120.

Kotler, P. T. (2019). Marketing management. Pearson UK.

Li, C., Negnevitsky, M., \& Wang, X. (2020). Prospective assessment of methanol vehicles in China using FANP-SWOT analysis. Transport Policy, 96, 60-75. doi: 10.1016/j.tranpol.2020.06.010.

Lu, M. T., Hsu, C. C., Liou, J. J. H., \& Lo, H. W. (2018). A hybrid MCDM and sustainability-balanced scorecard model to establish sustainable performance evaluation for international airports. Journal of Air Transport Management, 71, 9-19. doi: 10.1016/j.jairtraman.2018.05.008.

Marchi, G., Vignola, M., Facchinetti, G., \& Mastroleo, G. (2014). International market selection for small firms: a fuzzy-based decision process. European Journal of Marketing, 48(11/12), 2198-2212. doi: 10.1108/EJM-09-2012-0512.

Mentzer, J. T., DeWitt, W., Keebler, J. S., Min, S., Nix, N. W., Smith, C. D., \& Zacharia, Z. G. (2001). Defining supply chain management. Journal of Business Logistics, 22(2), 1-25. doi: 10.1002/j.2158-1592.2001.tb00001.x.

Mersland, R., Nyarko, S. A., \& Sirisena, A. B. (2020). A hybrid approach to international market selection: the case of impact investing organizations. International Business Review, 29(1), 101624. doi: 10.1016/j.ibusrev.201 9.101624.

Musso, F., \& Francioni, B. (2014). International strategy for SMEs: criteria for foreign markets and entry modes selection. Journal of Small Business and Enterprise Development, 21(2), 301-312. doi: 10.1108/JSBED-10-2013-0149.

Natarajarathinam, M., \& Nepal, B. (2012). A holistic approach to market assessment for a manufacturing company in an emerging economy. Industrial Marketing Management, 41(7), 1142-1151. doi: 10.1016/j.indmarman.2012.05.003.

Oey, E., Noviyanti, \& Sanny, L. (2018). Evaluating international market selection with multi-criteria decision making tools-a case study of a metal company in Indonesia. International Journal of Business Excellence, 16(3), 341-361. doi: 10.1504/IJBEX.2018.095645.

Ozturk, A., Joiner, E., \& Cavusgil, S. T. (2015). Delineating foreign market potential: a tool for international market selection. Thunderbird International Business Review, 57(2), 119-141. doi: 10.1002/tie.21686. 
Paley, N. (1999). The manager's guide to competitive marketing strategies. Boca Raton, FL: CRC Press.

Pamucar D., Ecer, F., Cirovic, G., \& Alrasheedi, M. (2020). Application of improved best-worst method in real-world problems. Mathematics, 8(3), 414. doi: $10.3390 /$ math8030414.

Papadopoulos, N., \& Denis, J. E. (1988). Inventory, taxonomy and assessment of methods for international market selection. International Marketing Review, 5(3), 38-51. doi: 10.1108/eb008357.

Papadopoulos, N., \& Martín, O. M. (2011). International market selection and segmentation: perspectives and challenges. International Marketing Review, 28(2), 132-149. doi: 10.1108/02651331111122632.

Ragland, C. B., Brouthers, L. E., \& Widmier, S. M. (2015). Institutional theory and international market selection for direct selling. Marketing Intelligence \& Planning, 33(4), 538-555. doi: 10.1108/MIP-02-2014-0033.

Rahman, S. H. (2003). Modelling of international market selection process: a qualitative study of successful Australian international businesses. Qualitative Market Research: An International Journal, 6(2), 119-132. doi: 10.1108/13522 750310470127.

Ramadani, V., Zendeli, D., Gerguri-Rashiti, S., \& Dana, L. P. (2018). Impact of geomarketing and location determinants on business development and decision making. Competitiveness Review, 28(1), 98-120. doi: 10.1108/CR-12-20160081.

Reid, S. D. (1981). The decision-maker and export entry and expansion. Journal of International Business Studies, 12(2), 101-112. doi: 10.1057/palgrave.jibs.849 0581.

Rezaei, J. (2015). Best-worst multi-criteria decision-making method. Omega, 53, 49-57. doi: 10.1016/j.omega.2014.11.009.

Robinson, S. J. Q., Hichens, R. E., \& Wade, D. R. (2001). The directional policy matrix-tool for strategic planning. Marketing: Critical Perspectives on Business and Management, 4, 103. doi: 10.1016/S0024-6301(78)80002-8.

Root, F. R. (1994). Entry strategies for international markets. Jossey-Bass.

Schoemaker, P. (2017). MABA analysis (General Electric Matrix), Web seminar, Amsterdam University of Applied Sciences. Retrieved from https://www.youtu be.com/watch?v=dWWg2dPSfgI (18.03 2020)

Schu, M., \& Morschett, D. (2017). Foreign market selection of online retailers-a path-dependent perspective on influence factors. International Business Review, 26(4), 710-723. doi: 10.1016/j.ibusrev.2017.01.001.

Schühly, A., \& Tenzer, H. (2017). A multidimensional approach to international market selection and nation branding in sub-Saharan Africa. Africa Journal of Management, 3(3-4), 236-279. doi: 10.1080/23322373.2017.1375812.

Sener, H. Y. (2014). Determining new markets using analytic hierarchy process: case study in Güral Porcelain. International Journal of Marketing Studies, 6(5), 149. doi: 10.5539/ijms.v6n5p149. 
Shen, L., Zhou, J., Skitmore, M., \& Xia, B. (2015). Application of a hybrid entropy-McKinsey Matrix method in evaluating sustainable urbanization: a China case study. Cities, 42, 186-194. doi: 10.1016/j.cities.2014.06.006.

Sheng, S. Y., \& Mullen, M. R. (2011). A hybrid model for export market opportunity analysis. International Marketing Review, 28(2), 163-182. doi: 10.1108/ 02651331111122650.

Solangi, Y. A., Tan, Q., Mirjat, N, H., \& Ali, S. (2019). Evaluating the strategies for sustainable energy planning in Pakistan: an integrated SWOT-AHP and Fuzzy-TOPSIS approach. Journal of Cleaner Production, 236, 117655. doi: 10.1016/j.jclepro.2019.117655.

Stević, Ž., Pamučar, D., Puška, A., \& Chatterjee, P. (2020). Sustainable supplier selection in healthcare industries using a new MCDM method: measurement of alternatives and ranking according to COmpromise solution (MARCOS). Computers \& Industrial Engineering, 140, 106231. doi: 10.1016/j.cie.2019.106231.

Torkayesh, A. E., \& Basit, M. N. (2020a). Application of BWM-WASPAS model for digital supplier selection problem: a case study in online retail shopping. Journal of Industrial Engineering and Decision Making, 1(1), 12-23. doi: 10.31181/jiedm200101012t.

Torkayesh, S. E., Amiri, A., Iranizad, A., \& Torkayesh, A. E. (2020b). Entropy based EDAS decision making model for neighborhood selection: a case study in istanbul. Journal of Industrial Engineering and Decision Making, 1(1), 1-11. doi: 10.31181/jiedm200101001t.

Tosun, N. (2017). Target market selection in fresh fruit-vegetable sector using Fuzzy VIKOR method. Journal of Management Marketing and Logistics, 4(4), 465-471. doi: 10.17261/Pressacademia.2017.734.

Vahlne, J. E., \& Johanson, J. (2013). The Uppsala model on evolution of the multinational business enterprise-from internalization to coordination of networks. International Marketing Review, 30(3), 189-210. doi: 10.1108/0265133 1311321963.

Varmazyar, M., Dehghanbaghi, M., \& Afkhami, M. (2016). A novel hybrid MCDM model for performance evaluation of research and technology organizations based on BSC approach. Evaluation and Program Planning, 58, 125140. doi: 10.1016/j.evalprogplan.2016.06.005.

Vernon, R. (1992). International investment and international trade in the product cycle. In International economic policies and their theoretical foundations. Academic Press, 415-435.

Whitelock, J., \& Jobber, D. (2004). An evaluation of external factors in the decision of UK industrial firms to enter a new non-domestic market: an exploratory study. European Journal of Marketing, 38(11/12), 1437-1455. doi: 10.1108/03 090560410560182.

Yang, W., \& Jiang, X. (2018). Evaluating sustainable urbanization of resourcebased cities based on the mckinsey matrix: case study in China. Journal of Urban Planning and Development, 144(1), 05017020. doi: 10.1061/(ASCE)UP .1943-5444.0000423. 
Yazdani, M., Zarate, P., Zavadskas, E. K., \& Turskis, Z. (2019a). A combined compromise solution (CoCoSo) method for multi-criteria decision-making problems. Management Decision, 57(9), 2501-2519. doi: 10.1108/MD-05-2017 $-0458$.

Yazdani, M., Hernandez, V. D., Chatterjee, P., \& Zavadskas, E. K. (2019b). A statistical approach for improvement of Best Worst Method (BWM). In 17th international colloquium „Sustainable decisions in built environment “. Vilnius: Gediminas Technical University.

Yazdani, M., Chatterjee, P., \& Torkayesh, A. E. (2020a). An integrated AHPQFD-based compromise ranking model for sustainable supplier selection. In Handbook of research on interdisciplinary approaches to decision making for sustainable supply chains. IGI Global, 32-54.

Yazdani, M., Torkayesh, A. E., \& Chatterjee, P. (2020b). An integrated decisionmaking model for supplier evaluation in public healthcare system: the case study of a Spanish hospital. Journal of Enterprise Information Management. 33(5), 965-989. doi: 10.1108/JEIM-09-2019-0294.

Zolfani, S. H., Yazdani, M., Pamucar, D., \& Zarate, P. (2020). A VIKOR and TOPSIS focused reanalysis of the MADM methods based on Logarithmic Normalization. Facta Universitatis, Series: Mechanical Engineering, 18(3), 341-355. doi: 10.22190/FUME191129016Z.

Žižović, M., \& Pamucar, D. (2019). New model for determining criteria weights: Level Based Weight Assessment (LBWA) model. Decision Making: Applications in Management and Engineering, 2(2), 126-137. doi: 10.31181/dmame19 $02102 \mathrm{z}$.

Zhu, Q., Sarkis, J., \& Lai, K. H. (2008). Green supply chain management implications for "closing the loop". Transportation Research Part E: Logistics and Transportation Review, 44(1), 1-18. doi: 10.1016/j.tre.2006.06.003. 


\section{Annex}

Table 1. Weight values of factors

\begin{tabular}{|c|c|c|c|c|c|}
\hline MA Criteria & $C_{I-1}$ & $C_{I-2}$ & $C_{1-3}$ & $C_{1-4}$ & $C_{1-5}$ \\
\hline Weight & 0.35 & 0.20 & 0.10 & 0.20 & 0.15 \\
\hline BA Criteria & $C_{2-1}$ & $C_{2-2}$ & $C_{2-3}$ & $C_{2-4}$ & $C_{2-5}$ \\
\hline Weight & 0.15 & 0.25 & 0.20 & 0.30 & 0.10 \\
\hline
\end{tabular}

Table 2. Initial matrix for market attractiveness

\begin{tabular}{cccccc}
\hline Market/Criteria & $\boldsymbol{C}_{\boldsymbol{I - 1}}$ & $\boldsymbol{C}_{\boldsymbol{l - 2}}$ & $\boldsymbol{C}_{\boldsymbol{I - 3}}$ & $\boldsymbol{C}_{\boldsymbol{I - 4}}$ & $\boldsymbol{C}_{\boldsymbol{l - 5}}$ \\
\hline Market 1 & 45 & 50 & 35 & 80 & 65 \\
Market 2 & 30 & 30 & 85 & 70 & 95 \\
Market 3 & 95 & 100 & 25 & 45 & 50 \\
Market 4 & 45 & 80 & 65 & 60 & 45 \\
Market 5 & 85 & 95 & 75 & 60 & 55 \\
Market 6 & 35 & 65 & 55 & 40 & 60 \\
\hline
\end{tabular}

Table 3. Initial matrix for business attractiveness

\begin{tabular}{cccccc}
\hline Market/Criteria & $\boldsymbol{C}_{\boldsymbol{2}-\boldsymbol{1}}$ & $\boldsymbol{C}_{\mathbf{2 - 2}}$ & $\boldsymbol{C}_{\mathbf{2 - 3}}$ & $\boldsymbol{C}_{\mathbf{2 - 4}}$ & $\boldsymbol{C}_{\mathbf{2}-\mathbf{5}}$ \\
\hline Market 1 & 25 & 20 & 35 & 85 & 75 \\
Market 2 & 80 & 65 & 55 & 70 & 95 \\
Market 3 & 55 & 25 & 75 & 95 & 60 \\
Market 4 & 45 & 95 & 90 & 100 & 45 \\
Market 5 & 15 & 30 & 30 & 50 & 65 \\
Market 6 & 35 & 30 & 85 & 80 & 50 \\
\hline
\end{tabular}

Table 4. EDAS values for market attractiveness

\begin{tabular}{lccc}
\hline & NSP & NSN & $\mathbf{A S}_{\mathbf{i}}$ \\
\hline Market 1 & 0.237 & 0.409 & 0.323 \\
Market 2 & 0.506 & 0.000 & 0.253 \\
Market 3 & 1.000 & 0.522 & 0.761 \\
Market 4 & 0.139 & 0.607 & 0.373 \\
Market 5 & 0.874 & 0.941 & 0.908 \\
Market 6 & 0.000 & 0.216 & 0.108 \\
\hline
\end{tabular}




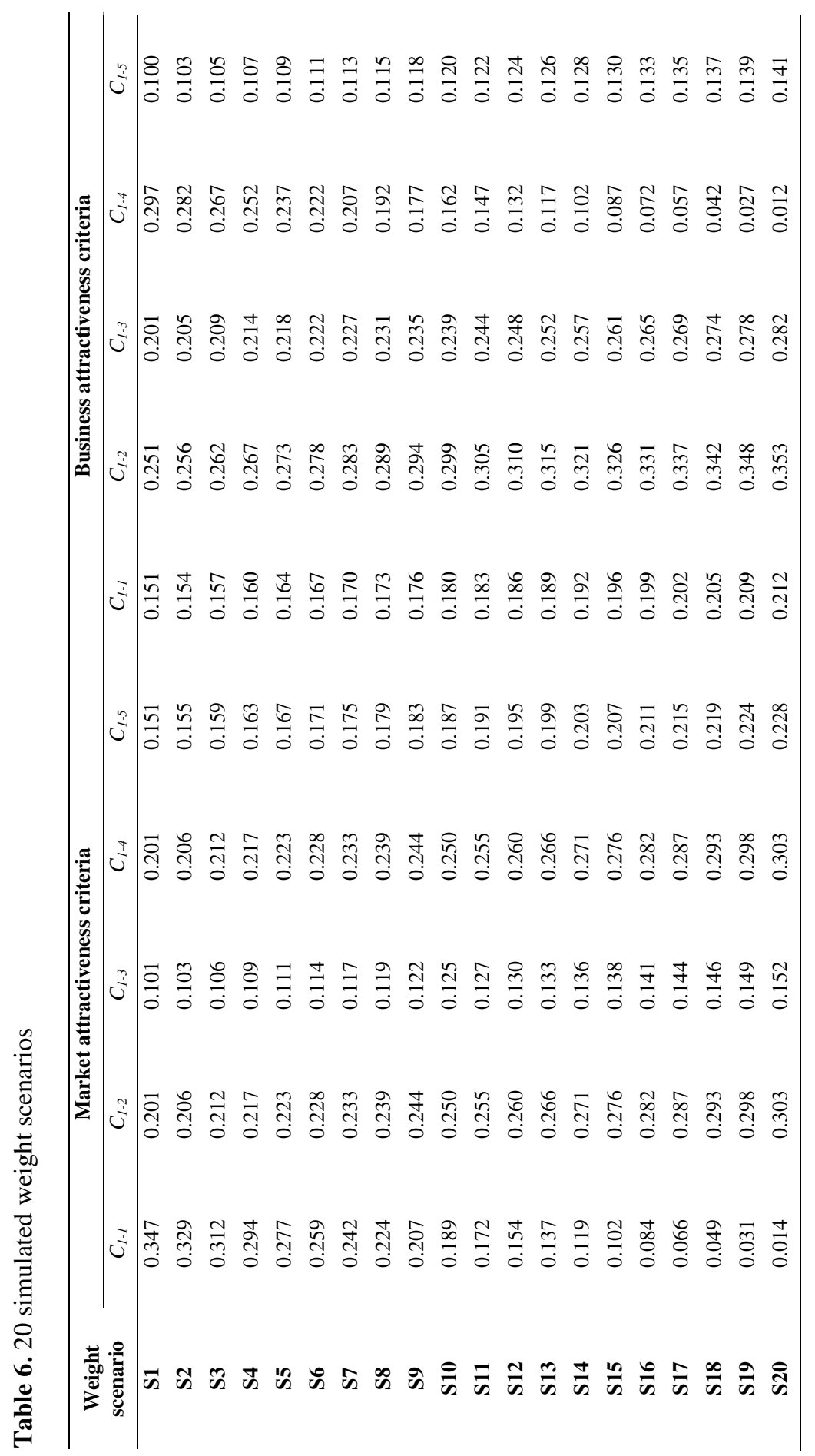




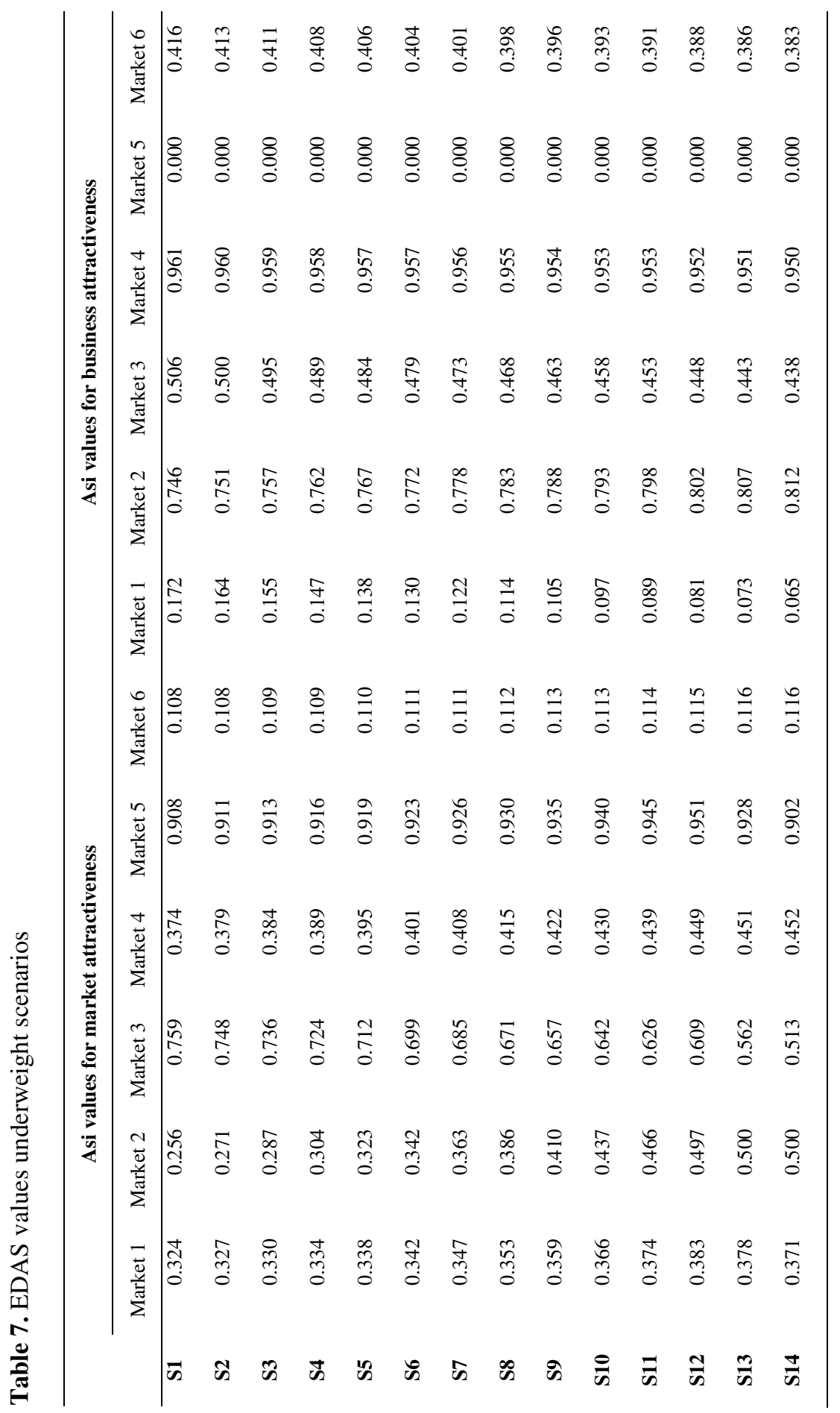




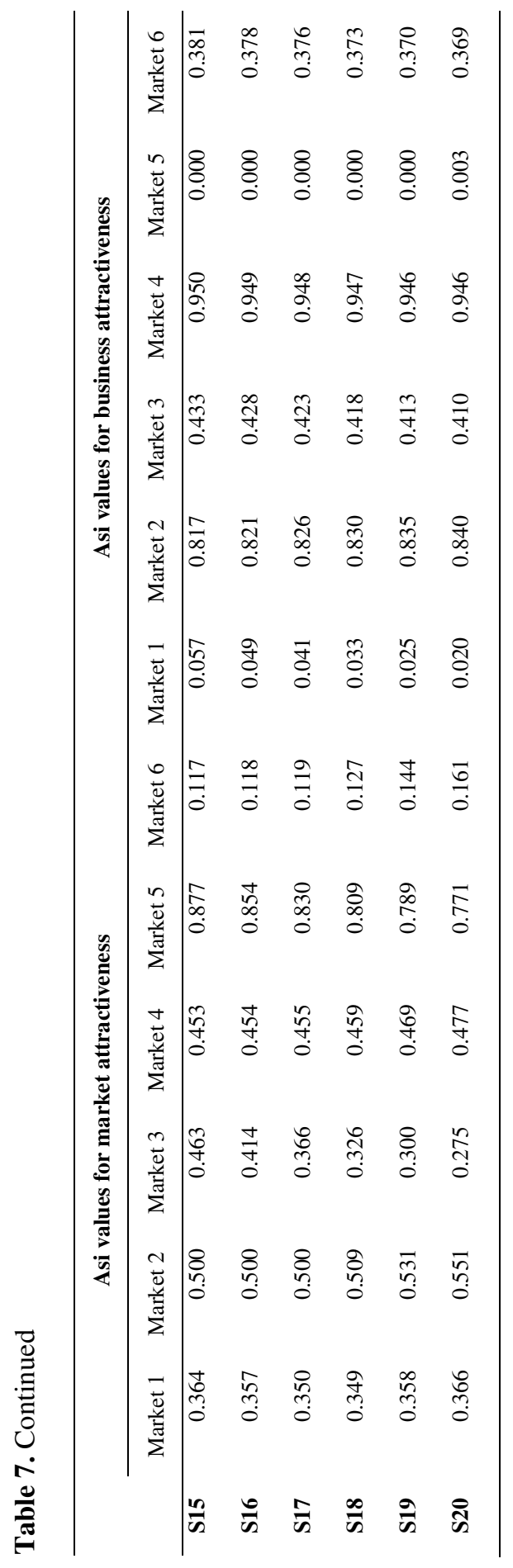


Table 5. EDAS values for business attractiveness

\begin{tabular}{llll}
\hline & NSP & NSN & $\mathbf{A S}_{\mathbf{i}}$ \\
\hline Market 1 & 0.074 & 0.274 & 0.174 \\
Market 2 & 0.640 & 0.849 & 0.744 \\
Market 3 & 0.310 & 0.704 & 0.507 \\
Market 4 & 1.000 & 0.922 & 0.961 \\
Market 5 & 0.000 & 0.000 & 0.000 \\
Market 6 & 0.163 & 0.669 & 0.416 \\
\hline
\end{tabular}


Figure 1. GE Matrix/MABA analysis

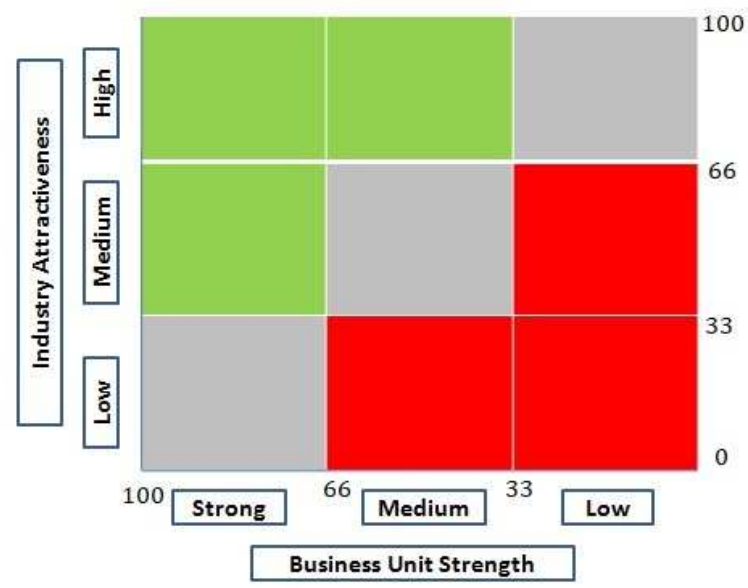

Figure 2. GE Matrix plot

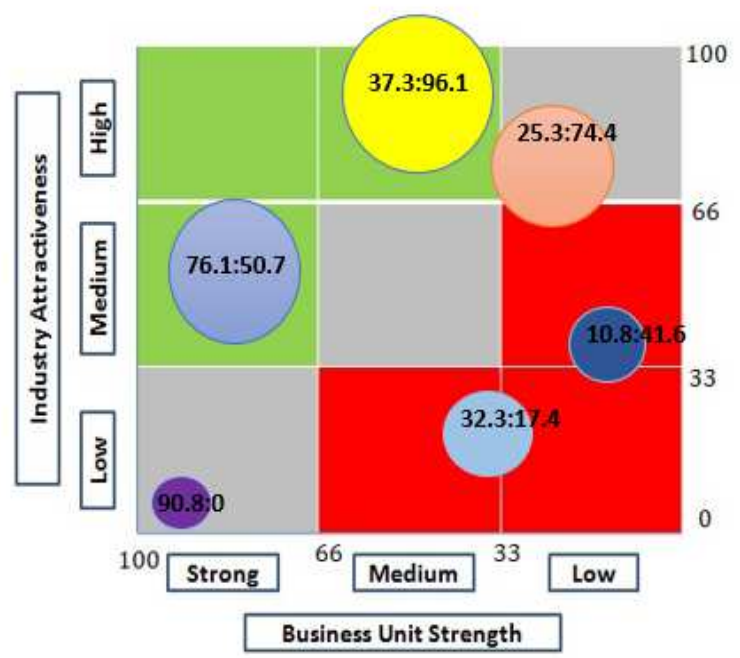


Figure 3. Weight scenarios for market attractiveness criteria

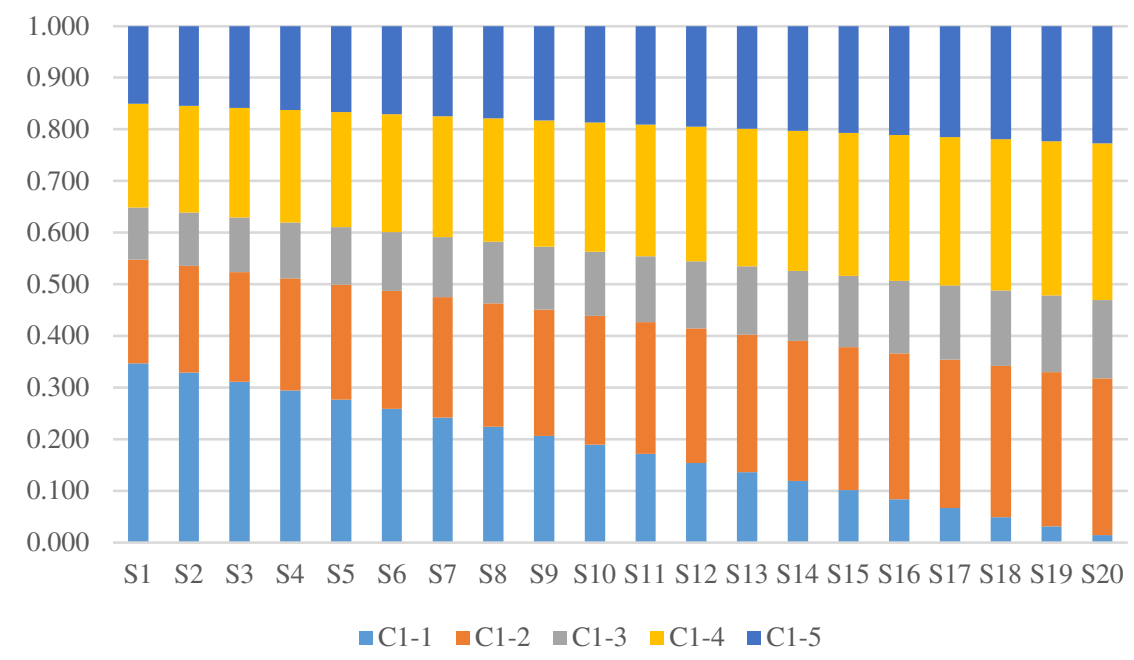

Figure 4. Weight scenarios for business attractiveness criteria

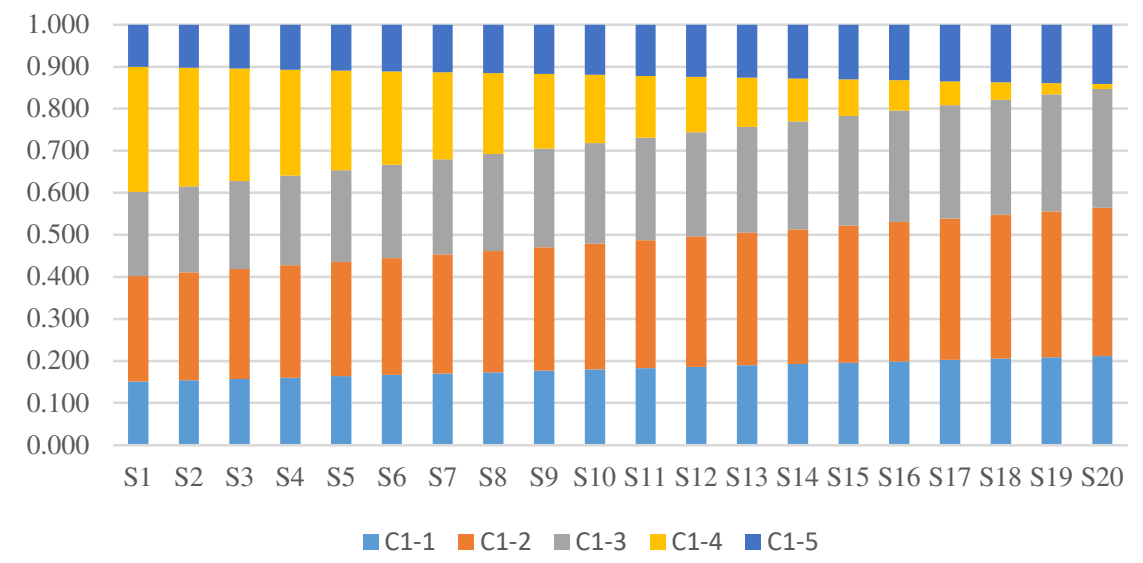

